\title{
Effect of Work Discipline and Training on Employee Performance of PT Federal International Finance Depok Branch
}

\author{
Agrasadya \\ Univesitas Pamulang \\ Email: dosen01866@unpam.ac.id
}

(Received: May 5-2020; revised: Juny 6-2020; published: Juny 30-2020)

\begin{abstract}
This study aims to determine the effect of work discipline and training on employee performance at PT. Federal International Finance Depok Branch. The method used is descriptive method with an associative approach, while to get the data done by distributing questionnaires to 90 respondents. The results of work discipline research have a positive and significant effect on employee performance by $33.10 \%$. Hypothesis testing obtained tcount $>$ ttable $(6.205>1.991)$, this is also strengthened by a probability of significance of $0,000<0.05$. Thus $\mathrm{H} 0$ is rejected and $\mathrm{H} 1$ is accepted meaning that there is an influence of work discipline on employee performance. Training has a positive and significant effect on employee performance by $44.7 \%$. Hypothesis testing obtained tcount> ttable (7.939> 1.991), this is also strengthened with a significance probability of $0,000<0.05$. Thus $\mathrm{H} 0$ is rejected and $\mathrm{H} 1$ is accepted meaning that there is an influence of training on employee performance. Work discipline and training have a positive and significant effect on employee performance with a regression equation $\mathrm{Y}=10.884+$ $0.247 \mathrm{X} 1+0.495 \mathrm{X} 2$. These results indicate the coefficient of work discipline variables of 0.247 and training of 0.495 , all variables are positive meaning that the better discipline and training, the better the performance of employees. The contribution of the influence of work discipline and training was 50.3\% while the remaining $49.7 \%$ was influenced by other factors. Hypothesis testing obtained Fcount> Ftable $(46,364>3,100)$ this is reinforced by the F-Probability significance of $0,000<0.05$, thus H0 is rejected and $\mathrm{H} 3$ is accepted meaning that there is a positive and significant influence between work discipline and training simultaneously on the performance of employees of PT. Federal International Finance Depok Branch.
\end{abstract}

Keywords: Work discipline; training; employee performance.

\section{INTRODUCTION}

In the development of globalization, many companies are demanded to be able to maximize employee performance better in the era of globalization. Companies in Indonesia continue to experience competition that is so tight that companies must further improve their companies, especially in the HR (human resources) sector to face competition. very strict (Norani, Amirullah, \& Darwis, 2015; Saleh \& Darwis, 2016). The issue of human resources is a very important concern for companies to remain viable (Hasibuan, 2011; Mathis \& Jackson, 2002; Singodimendjo, 2011; Sulistiyani \& Rosidah, 2013). Companies are required to be able to obtain, develop and maintain quality human resources. Work discipline can be seen as something of great benefit both to the interests of the organization and to employees (S. Doyle, 2019; Vosloban, 2012; Waris, 2015).

A company, human resource potential is essentially one of the capital and holds the most important role in achieving company goals (Alwi, 2008; Handoko, 2010; Raudeliūnienè \& Meidutè-Kavaliauskienè, 2014). Therefore companies need to manage human resources as well 


\section{Jurnal Ilmiah Ilmu Administrasi Publik: Jurnal Pemikiran dan Penelitian Administrasi Publik Volume 1o Number 1, January - June 2020. Page 15-24}

as possible. Because the key to a company's success is not only in technological excellence and the availability of funds. But the human factor is the most important factor as well.

A way related to human resources in order to become a source of competitive advantage is through increasing human capital to be able to recognize and adapt to an ever changing environment (Blaga \& Jozsef, 2014; Sinambela, 2016). Nowadays the growth of the business environment which is very fast demands the role of human resources in competitive advantage, this also means that companies must be able to improve the work achieved now to be able to obtain better work in the future. One factor that is very influential in human resources is the discipline factor.

According to Hasibuan (2018), discipline is an awareness of one's willingness to comply with all company regulations and applicable norms. If the working environment is all disciplined, then an employee will be disciplined, but if the company's work environment is not disciplined, then an employee will also be undisciplined. For this reason it is very difficult for an undisciplined work environment but wants to apply employee discipline, because the work environment will be a role model for employees.

Work discipline can be seen as something of great benefit, both for the interests of the company and for employees, for the company the existence of work discipline will guarantee the maintenance of order and the smooth implementation of tasks so that optimal results are obtained. As for employees, a pleasant working atmosphere will be obtained so that it will increase morale in carrying out their work. Thus, employees can carry out their duties with full awareness and can develop energy and mind to the fullest.

In carrying out the daily tasks of discipline often becomes an obstacle in an organization, the low level of discipline becomes a recurring problem. From the results of the prariset that the author did, the following inequality that occurs where when the company is promoting a performance program that is useful, but precisely in this company work discipline shows unfavorable trends, such as arriving late, often leaving work prematurely. The results of observations made by the author at the study site are the application of good employee performance in this case is the level of attendance and achievement of targets that are felt to be not optimal so that company goals cannot be fully achieved. These conditions are shown in table 1.

\section{Table 1}

Employee Absenteeism Data of PT Federal International Finance (FIF) Depok Branch for the 2014-2018 Period

\begin{tabular}{|c|c|c|c|c|c|c|c|}
\hline \multirow[t]{2}{*}{ Years } & \multirow{2}{*}{$\begin{array}{c}\text { Number } \\
\text { of } \\
\text { working } \\
\text { days }\end{array}$} & \multicolumn{4}{|c|}{ Kriteria } & \multirow[b]{2}{*}{ amount } & \multirow[b]{2}{*}{$\begin{array}{c}\text { Average } \\
(\%)\end{array}$} \\
\hline & & Late & Permission & $\begin{array}{c}\text { Without } \\
\text { permission }\end{array}$ & $\begin{array}{l}\text { Come } \\
\text { home } \\
\text { early }\end{array}$ & & \\
\hline 2014 & 264 & 13 & 15 & 11 & 16 & 55 & $20.8 \%$ \\
\hline 2015 & 264 & 18 & 21 & 14 & 20 & 73 & $27.7 \%$ \\
\hline 2016 & 264 & 24 & 20 & 18 & 22 & 84 & $31.8 \%$ \\
\hline 2017 & 264 & 18 & 16 & 25 & 25 & 84 & $31.8 \%$ \\
\hline 2018 & 264 & 22 & 20 & 28 & 27 & 97 & $36.7 \%$ \\
\hline \multicolumn{2}{|c|}{ Average (people) } & 19 & 18.4 & 19.2 & 22 & 78.6 & $29.8 \%$ \\
\hline
\end{tabular}


Based on table 1, shows that the high absenteeism of employees who are late, permit, without permission and leave early from 2014 to 2018 as a whole is in poor condition, where from all good employees who arrived late reached an average of 19, permitted employees reached an average of 18.4 employees without permits, averaging 19.2, and employees who left earlier reached 22 people. Overall shows an increasing trend from every year, this indicates there are still many employees who lack discipline in work where as a whole reaches an average of $29.8 \%$.

Training and development are the most important things in human resource management for professionals and managers. Training for employees is very important, since it is known that people's knowledge gained from formal education is not enough or is not suitable for the company. According to Sinambela (2016) in today's modern management view, humans are no longer merely positioned as the main resource, but more than that, namely that humans have become the assets of the organization in the future or more popularly known as the concept of human capital. Well-designed training can actually measure benefits such as improving the health and performance of managers and employees.

According to Mangkunegara (2003) stated that training (training) is a short-term educational process that uses systematic and organized procedures, non-managerial employees learn technical knowledge and skills in limited goals. More and more employees are given the opportunity to attend training can improve company performance. However, in reality this matter is actually not getting priority by the company management as evidenced from the data collected showing fluctuating conditions.

In practice, most companies want high performance but do not try to increase the work motivation of their human resources. This becomes difficult in realizing the performance to be achieved for it needs to be further investigated whether the motivation of employees at work. Companies can not only be satisfied if they succeed in making employees not change jobs, but whether employees who have worked for a long time already have the right motivation. This is a challenge for every company that wants to improve its performance.

\section{METHOD}

The type of data used is quantitative from primary data sources by distributing questionnaires which are then carried out tabulation and feasibility analysis as well as secondary data from various scientific literature. The population in this study were employees of PT. Federal International Finance Depok Branch. Sampling was used saturation sampling technique that is 80 employees. The instrument testing uses validity and reliability tests. From the test of validity and reliability stated valid and reliable, this is evidenced by the value of $r_{\text {count }}>r_{\text {table }}$, as well as the instrument used is appropriate and feasible to be forwarded to the next test. Testing for normality using Kolmogorov Smirnof obtained significance greater than 0.50 and thus declared normal. Multicollinearity testing obtained tolerance values $<1$ and VIF $<10$ so that it was concluded there was no interference with multicollinearity. Autocorrelation testing obtained the value of Durbin-Watson at an interval of 1.550 - 2.460, thus this regression model does not have autocorrelation. Heteroskesdastisitas test with Glejser test obtained significance value greater than 0.05 so it was concluded that there was no interference with heteroskesdasticity. 
18 Jurnal Ilmiah Ilmu Administrasi Publik: Jurnal Pemikiran dan Penelitian Administrasi Publik Volume 10 Number 1, January - June 2020. Page 15-24

\section{RESULT AND DISCUSSION}

PT. FIF Group is a subsidiary of PT. Astra Honda Motor. The company was formed as a management response to increasing the growth of the motorcycle market as a choice of the community in terms of having the means of transportation. With PT. FIF as a motorcycle financing company, consumers will have the flexibility in calculation and payment capabilities that are tailored to the conditions of consumers.

The criteria of the object under study are based on respondents' responses to the questions about work discipline variables (X1) obtained an average score of 3.84, training variables (X2) of 3.85 and employee performance variables $(\mathrm{Y})$ of 3.92, to three variables were obtained all scores were in the scale range of 3.40 - 4.19 with good criteria.

\section{Descriptive Analysis}

The criteria of the object under study are based on respondents' responses to the questions about work discipline variables (X1) obtained an average score of 3.84, training variables (X2) of 3.85 and employee performance variables $(\mathrm{Y})$ of 3.92 , to three variables were obtained all scores were in the scale range $3.40-4.19$ with good criteria.

\section{Multiple Linear Regression Analysis}

This multiple regression test is intended to find out how much influence $\mathrm{X} 1$ and $\mathrm{X} 2$ variables have on the $\mathrm{Y}$ variable. In this study work discipline (X1) and training (X2) on employee performance (Y). The following are the results of processed regression data with SPSS which can be seen in the following table:

\section{Table 2}

\section{Work Disciplinary Regression (X1) and Training (X2) Results on Employee Performance} (Y)

\section{Coefficients $^{\mathrm{a}}$}

\begin{tabular}{|c|c|c|c|c|c|c|}
\hline \multirow{2}{*}{\multicolumn{2}{|c|}{ Model }} & \multicolumn{2}{|c|}{$\begin{array}{l}\text { Unstandardized } \\
\text { Coefficients }\end{array}$} & \multirow{2}{*}{$\begin{array}{l}\text { Standardized } \\
\text { Coefficients } \\
\text { Beta }\end{array}$} & \multirow[b]{2}{*}{$\mathrm{t}$} & \multirow[b]{2}{*}{ Sig. } \\
\hline & & $\mathrm{B}$ & Std. Error & & & \\
\hline \multirow[t]{3}{*}{1} & (Constant) & 10.844 & 3.233 & & 3.354 & .001 \\
\hline & Work discipline (X1) & .247 & .084 & 288 & 2.953 & .004 \\
\hline & Training (X2) & .495 & .096 & .505 & 5.173 & .000 \\
\hline
\end{tabular}

a. Dependent Variable: Employee Performance (Y)

Based on the results of the regression calculations in the above table, the regression equation $\mathrm{Y}=10.844+0.247 \mathrm{X} 1+0.495 \mathrm{X} 2$ can be obtained. A constant value of 10.844 means that if the variables $\mathrm{X} 1$ and $\mathrm{X} 2$ do not exist then there is a value of 10.844 points. A value of 0.247 is interpreted if the constant is constant and there is no change in the $\mathrm{X} 2$ variable, then every 1 unit change in the $\mathrm{X} 1$ variable will result in a change in $\mathrm{Y}$ of 0.247 points. A value of 
0.495 is interpreted if the constant is constant and there is no change in the $\mathrm{X} 1$ variable, then every 1 unit change in the $\mathrm{X} 2$ variable will result in a change in $\mathrm{Y}$ of 0.495 points.

\section{Determination Coefficient Analysis (R Square)}

Analysis of the coefficient of determination is intended to determine the percentage strength of the relationship between the independent variables on the dependent variable both partially and simultaneously, in this study the variables of work discipline and training on employee performance. Here are the results of the calculation of the coefficient of determination seen in the table 3.

\section{Table 3}

Partial Determination Coefficient Analysis Results Work Discipline (X1) on Employee Performance (Y)

\begin{tabular}{ll|lll}
\multicolumn{5}{c}{ Model Summary } \\
\hline Model & R & R Square & Adjusted R Square & Std. Error of the Estimate \\
\hline 1 & $.575^{\text {a }}$ & .331 & .322 & 3.022 \\
\hline
\end{tabular}

a. Predictors: (Constant), work discipline (X1)

Based on the table above, obtained R-square value (coefficient of determination) of 0.331 , it can be concluded that the work discipline variable (X1) affects the employee performance variable $(\mathrm{Y})$ by $33.1 \%$ while the remaining $66.9 \%$ is influenced by other factors .

\section{Table 4}

Results of Partial Determination Coefficient Analysis of Training variables (X2) on Employee Performance (Y)

\begin{tabular}{ll|lll}
\multicolumn{5}{c}{ Model Summary } \\
\hline Model & R & R Square & Adjusted R Square & Std. Error of the Estimate \\
\hline 1 & $.669^{\text {a }}$ & .447 & .440 & 2.747 \\
\hline
\end{tabular}

a. Predictors: (Constant), training (X2)

Based on the table above, the R-square value of 0.447 is obtained, it can be concluded that the training variable (X2) influences the employee performance variable (Y) by $44.7 \%$ while the remaining $55.3 \%$ is influenced by other factors. 
20 Jurnal Ilmiah Ilmu Administrasi Publik: Jurnal Pemikiran dan Penelitian Administrasi Publik Volume 10 Number 1, January - June 2020. Page 15-24

Table 5

Results of Simultaneous Determination Coefficient Analysis between Work Discipline (X1) and Training (X2) on Employee Performance (Y)

\begin{tabular}{lllll}
\multicolumn{4}{c}{ Model Summary } \\
\hline Model & $\mathrm{R}$ & R Square & $\begin{array}{l}\text { Adjusted } \\
\text { Square }\end{array}$ & R \\
\hline 1 & $.709^{\mathrm{a}}$ & .503 & .490 & 2.620 \\
\hline
\end{tabular}

a. Predictors: (Constant), Pelatihan (X2), Disiplin Kerja (X1)

Based on the table above, an R-square value of 0.503 is obtained, it can be concluded that the work discipline variable (X1) and training (X2) affect the employee performance variable (Y) by $50.3 \%$ while the remaining $49.7 \%$ is influenced by factors Other research that was not done.

\section{Hypothesis test}

The effect of work discipline (X1) on employee performance $(\mathrm{Y})$ of data processing using SPSS version 24, with the results of table 6 .

Table 6

T Test Results Variable Work Discipline (X1) on Employee Performance (Y)

Coefficients $^{\mathrm{a}}$

\begin{tabular}{|c|c|c|c|c|c|c|}
\hline \multirow{2}{*}{\multicolumn{2}{|c|}{ Model }} & \multicolumn{2}{|c|}{$\begin{array}{l}\text { Unstandardized } \\
\text { Coefficients }\end{array}$} & \multirow{2}{*}{$\begin{array}{c}\text { Standardized } \\
\text { Coefficients } \\
\text { Beta }\end{array}$} & \multirow[b]{2}{*}{$\mathrm{t}$} & \multirow[b]{2}{*}{ Sig. } \\
\hline & & $\mathrm{B}$ & Std. Error & & & \\
\hline 1 & (Constant) & 20.409 & 3.059 & & 6.672 & .000 \\
\hline & Disiplin Kerja (X1) & .493 & .079 & .575 & 6.205 & .000 \\
\hline
\end{tabular}

a. Dependent Variable: employee performance (Y)

Based on table 6 , the value of tcount $>t$ table or $(6.205>1.991)$ is also strengthened by the value of $\rho$ value $<$ Sig. 0.05 or $(0,000<0.05)$. Thus, $\mathrm{H} 0$ is rejected and $\mathrm{H} 1$ is accepted, this shows that there is a positive and partially significant effect between work discipline on employee performance. The results of data processing using SPSS version 24, with the results of table 7. 


\section{Table 7}

\section{Training Hypothesis (X2) Results on Employee Performance (Y)}

\begin{tabular}{|c|c|c|c|c|c|}
\hline \multicolumn{6}{|c|}{ Coefficients ${ }^{\mathrm{a}}$} \\
\hline & $\begin{array}{r}\text { Unsta } \\
\text { Coe }\end{array}$ & $\begin{array}{l}\text { dardized } \\
\text { icients }\end{array}$ & $\begin{array}{l}\text { Standardized } \\
\text { Coefficients }\end{array}$ & & \\
\hline Model & B & Std. Error & Beta & $\mathrm{t}$ & Sig. \\
\hline $\begin{array}{ll}1 & \text { (Constant) }\end{array}$ & 14.149 & 3.180 & & 4.450 & .000 \\
\hline Training (X2) & .655 & .082 & .669 & 7.939 & .000 \\
\hline
\end{tabular}

a. Dependent Variable: employee performance (Y)

Based on table 7, the value of tcount $>t$ table or $(7.939>1.991)$ is also strengthened by the value of $\rho$ value $<$ Sig. 0.05 or $(0,000<0.05)$. Thus, H0 is rejected and H2 is accepted, this shows that there is a positive and partially significant effect between training on employee performance.

\section{Table 8}

Hypothesis Results (Test F) Simultaneously Work Discipline (X1) and Training (X2) variables on Employee Performance ( $Y$ )

\begin{tabular}{llr|r|r|r|r}
\multicolumn{7}{c}{ ANOVA $^{\mathrm{a}}$} \\
\hline \multicolumn{1}{l}{ Model } & Sum of Squares & \multicolumn{1}{c}{ df } & Mean Square & F & \multicolumn{1}{c}{ Sig. } \\
\hline 1 & Regression & 535.369 & 2 & 267.685 & 38.994 & $.000^{\mathrm{b}}$ \\
\cline { 2 - 8 } & Residual & 528.581 & 77 & 6.865 & & \\
\cline { 2 - 8 } & Total & 1063.950 & 79 & & & \\
\hline
\end{tabular}

a. Dependent Variable: employee performance (Y)

b. Predictors: (Constant), training (X2), work discipline (X1)

Based on the above table, the value of Fcount $>$ Ftable or (38.994> 3.120) is obtained, this is also reinforced by the $\rho$ value $<$ Sig. 0.05 or $(0,000<0.05)$. Thus, H0 is rejected and H3 is accepted, this shows that there is a positive and significant effect simultaneously between work discipline and training on employee performance.

\section{CONCLUSION}

Work discipline has a positive and significant effect on employee performance with an influence contribution of $35.0 \%$. Hypothesis testing is obtained tcount $>$ ttable or $(6.887>1.987$, thus $\mathrm{H} 0$ is rejected and $\mathrm{H} 1$ is accepted meaning there is a positive and significant influence between work discipline on employee performance. Training has a positive and significant effect on employee performance with a contribution of $45.5 \%$. Hypothesis testing is obtained $\mathrm{t}_{\text {count }}>\mathrm{t}$ table or $(8.578>1.987)$, thus $\mathrm{H} 0$ is rejected and $\mathrm{H} 2$ is accepted meaning that there is a positive and significant effect between training on employee performance Work discipline and training simultaneously have a positive and significant effect on employee performance with regression equation $\mathrm{Y}=10.908+0.262 \mathrm{X} 1+0.479 \mathrm{X} 2$ The contribution of influence 
22 Jurnal Ilmiah Ilmu Administrasi Publik: Jurnal Pemikiran dan Penelitian Administrasi Publik Volume 10 Number 1, January - June 2020. Page 15-24

simultaneously is $51.6 \%$ while the remaining $48.4 \%$ is influenced by other factors Hypothesis testing is obtained Fcount> Ftable or $(46,364>3,100)$, thus $\mathrm{H} 0$ is rejected and $\mathrm{H} 3$ is accepted, meaning that there is a positive and significant simultaneous effect between disciplines work and training on employee performance. This research means that if a company wants to improve performance, it can be done by increasing work discipline and training. Increased training has more impact than increased work discipline.

\section{REFERENCES}

Alwi, S. (2008). Manajemen Sumber Daya Manusia Strategi Keunggulan Kompetitif. BPFE UGM, Yogyakarta.

Blaga, P., \& Jozsef, B. (2014). Human Resources, Quality Circles and Innovation. Procedia Economics and Finance, 15, 1458-1462. https://doi.org/https://doi.org/10.1016/S22125671(14)00611-X

Doyle, S. (2019). Section 6 - Discipline-Specific Quality Management (S. B. T.-Q. M. in F. S. Doyle, ed.). https://doi.org/https://doi.org/10.1016/B978-0-12-805416-1.00006-2

Handoko, H. (2010). Manajemen Personalia Sumber Daya Manusia, Edisi Kedua. In BPFE UGM Persada. https://doi.org/10.4324/9780203488430

Hasibuan. (2018). Manajemen Sumber Daya Manusia. In Manajemen Sumber Daya Manusia.

Hasibuan, M. S. P. (2011). Manajemen Sumber Daya Manusia. Edisi Revisi Jakarta: Bumi Aksara.

Mangkunegara, A. A. A. P. (2003). Manajemen Sumber Daya Manusia Perusahaan. In Remaja Rosdakarya. https://doi.org/10.1038/cddis.2011.1

Mathis, R. L., \& Jackson, J. H. (2002). Human resource management: Manajemen sumber daya manusia. In Terjemahan Dian Angelia. Jakarta: Salemba Empat.

Norani, M., Amirullah, A. H., \& Darwis, M. (2015). Efektivitas Kinerja Pegawai pada Kantor Kementerian Agama Kota Makassar. Jurnal Office, 1(1), 1-7.

Raudeliūnienè, J., \& Meidutè-Kavaliauskienè, I. (2014). Analysis of Factors Motivating Human Resources in Public Sector. Procedia - Social and Behavioral Sciences, 110, 719-726. https://doi.org/https://doi.org/10.1016/j.sbspro.2013.12.916

Saleh, S., \& Darwis, M. (2016). Pengaruh Tunjangan Kinerja Terhadap Kinerja Pegawai Pada Bauk Universitas Negeri Makassar. Jurnal Ilmiah Ilmu Administrasi Publik, 5(2), 121130.

Sinambela, L. P. (2016). Manajemen Sumber Daya Manusia, Membangun Tim Kerja yang Solid untuk Meningkatkan Kinerja.

Singodimendjo. (2011). Manajemen Sumber Daya Manusia. Jakarta: Bumi Aksara.

Sulistiyani, A. T., \& Rosidah. (2013). Manajemen Sumber Daya Manusia. Yogyakarta: Gadjah 
Mada University Press.

Vosloban, R. I. (2012). The Influence of the Employee's Performance on the Company's Growth - A Managerial Perspective. Procedia Economics and Finance, 3, 660-665. https://doi.org/https://doi.org/10.1016/S2212-5671(12)00211-0

Waris, A. P. M. dan A. (2015). Effect of Training, Competence and Discipline on Employee Performance in Company (Case Study in PT. Asuransi Bangun Askrida). Procedia Social and Behavioral Sciences. https://doi.org/10.1016/j.sbspro.2015.11.165 
24 | Jurnal Ilmiah Ilmu Administrasi Publik: Jurnal Pemikiran dan Penelitian Administrasi Publik Volume 1o Number 1, January - June 2020. Page 15-24 